UDC $82-95 ; 821.111(73)$

DOI https://doi.org/110.32838/2710-4656/2021.5-2/22

Shkuropat M. Yu.

Horlivka Institute for Foreign Languages of the State Higher Educational Institution

"Donbas State Pedagogical University"

\title{
“IT'S SHIT, BUT IT SELLS": ART AND CRAFT IN ERASURE AND THE WATER CURE BY PERCIVAL EVERETT
}

The article deals with the subject matter of art and craft as they are explored in the novels by a contemporary American writer Percival Everett Erasure and The Water Cure. Everett's novels testify that the author takes the subject of art so seriously that he returns to it again at later stages of his writing career. Moreover, he does not change the perspective but amplifies it providing the ground for comparison and contrasting analysis. The research makes an attempt to trace the unfolding of the concept of the art of writing as a threefold set of skills: cognitive, creative, and artistic, as opposed to the concept of craft understood here as skillful reproduction of the existing pattern. The analysis of the subject representation in both novels is done in a comparative mode and reveals its relation to the theme of authorial identity of a black author in the American culture. When art is viewed exclusively from a commercial viewpoint, sales criteria are applied not only to the form and content but to the identity of the author. Everett raises the issue of race in the context of the professional writing activity. Racial identity obviously plays a significant role in a consumer society and has to fit a certain expected standard of a certain genre, alongside the catchy titles, specific language, types of characters, and twists and turns of the plot. Black writers either have to succumb to the publisher's demands and start reflecting on the "black experience" or twist their authorial identity and write race and gender unspecific marketable fiction. It is argued that the protagonists'understanding of the art and craft issue has a strong reference to the author's view on it. Everett doesn't stop wrestling both with scholars and publishers against categorizing literature by the color of the author's skin.

Key words: art, craft, authorial identity, Percival Everett, Erasure, The Water Cure.

Problem statement. Drawing the line between the concepts of art and craft is impossible as they have been blended together through centuries of human creative activity. However, when it comes to literature as a verbal art, attempts have been made to show the difference between the two. One point of view on the art and craft of writing is that they are inseparable. Making art means using threefold set of skills: cognitive skills of discovering ideas combined with creative skills of self-expression accompanied with artistic skills of using the language in its full richness. The craft of writing involves learning and observing certain rules and common techniques of telling a story and creating word pictures in the mind of the reader.

Another approach suggests distinguishing between the concepts of art and craft. Making art is viewed as a process invigorating consciousness and thoughts, putting all of the creative powers at work. Art is often described as a spontaneous and open-ended form of work. It pushes the boundaries of imagination; the artists are never sure where their art would take them. Crafting is different. Being also a product of the mind, it largely relies on skills and techniques to meet the desired outcome. Sally J. Markowitz suggests that although art and craft are similar in a certain way, art has a positive evaluative connotation, but craft does not. [1]. Art has aesthetic and emotional value and translates its influence on the recipient. It has limitless expressions and allows multiple interpretations, while craft is aimed at producing functional objects, serving particular needs. And, finally, the main difference is that the real art is always single and individual. It cannot be duplicated, less so done for mass production, while craft can be easily reproduced on demand of consumers as it aims at mass production. Hence, the artist is someone capable of creating a once in a lifetime inimitable art work, while craftsman is someone skilled in producing replicable forms by demand.

Objective statement. This paper aims at showing how the subject matter of art and craft revealed through authorial identity is explored in Percival Everett's novels Erasure (2001) and The Water Cure (2007). The objectives of the study involve comparing and contrasting the ways of unfolding the subject matter in both novels; revealing the perspective of the author on the subject matter. 
Analysis of recent research and publications. Percival Everett has produced an impressive literary output and is known in the reading audience as a master of the art of creative expression in different literary genres. Unfortunately this author has been little known outside the circle of academic and avant-garde writers so far even in the US. The reason for that is that he is too difficult for an average reader to understand and "not black enough" for the publishing industry aimed at mass production. It means that in his works the author resists from reflecting the true experience of "black life" desired by the common reader. Critics admit Everett to be dauntingly erudite, relentlessly allusive, and ironic. He is appreciated by scholars for demanding style, challenging techniques of narration, precise take on a subject matter. However, Keith B. Mitchell and Robin G. Vander in the Introduction to the collection of essays on P. Everett (2013) write that in spite of "overwhelmingly positive reception that Everett and his work have garnered, there has been an astounding dearth of critical and scholarly examination on his fiction" $[2, \mathrm{p} . \mathrm{X}]$. They even call this "scandalous", because more European scholars study Everett's works than American ones. French scholars ((S. Bauer [3], M. Feith [4], C. A.-L. Tissut [5]) scrutinize Everett's texts through the lens of popular structuralistic theories struggling to decipher the meaning. American scholars (J. Dittman, S. Griffin, A. Stewart, R. Schur, [2], U. Cannon [6], J. Roof [7], M. Russett [8]) analyze theoretical aspects of text structure or argue about racial and identity problems discussed in his works. Although the topic of art, quite predictably, could not escape the researchers' attention (M. Feith, S. Morton [9], A. Stewart [10]), Everett's perspective on the subject matter of art and craft in his novels "Erasure" and "The Water Cure" have never been specifically studied in a comparative mode.

Main body. Percival Everett expressed his view on the subject of art in numerous interviews and publications. Firstly, he doesn't stop wrestling both with scholars and publishers against pigeonholing him as an African-American writer, by the color of his skin. Such categorization imposes certain stereotypes on his writing and segregates his reading audience accordingly. Secondly, he insists on viewing him as an artist capable of making high art irrespective of his racial background: "I don't want to talk about race," "I just want to make art" [10, p. 296] - he declares in one of the interviews. Unfair situation with black authors in American culture, experienced in his own career, made Everett bring the subject of art and race literary on the front page of his 2001 novel Erasure, which acted as a exploder for a heated discussion among critics and scholars. That is how the ideas about art expressed in Erasure through the mouthpiece of Thelonious Ellison (Monk), the protagonist writer of fiction, came to be viewed as the author's artistic manifesto which was further developed in 2007's novel The Water Cure .

The subject matter of art vs craft is explored in both novels in close connection to the subject matter of authorial identity. To introduce the subject, Everett constructs complex identities of his protagonists, who are both the authors of fiction. In both novels the protagonists have to disguise themselves for the publishers and produce formulaic genre fiction to become critically acclaimed and commercially successful. Thelonious Ellison (Monk), the protagonist of Erasure, and author of intellectual fiction, produced one 'piece of shit' tough ghetto-style novel under the pseudonym Stagg Leigh, which caused a lot of pain to his authorial dignity. Ishmael Kidder, the protagonist of The Water Cure, made writing romance novels under the identity of a write female writer his only way of making a living, having ducktaped his own masculine intellectual authorial voice in the back of his mind [11].

Everett implies that the art of writing involves a threefold set of skills: cognitive, creative and artistic. Both of his writers, having shaped their creative mindset by reading the best books of world classics, profess writing intellectual fiction. Monk actively supplies publish houses with his "unpalatable" novels based on "retelling of Euripides and parodies of French poststructuralists" [12, p. 2] and gets rejected. Kidder, having never ever published a desired piece of intellectual fiction, tortures the reader with bits and pieces of complicated philosophical discussions, conversations with outstanding minds, analysis of his country's external policies, allusions on other books, transformations of famous set phrases. Everett has trained cognitive skills of his fictional writers to perfection, making the reader believe in their relentless erudition, ability to acquire knowledge, manipulate information and give reasoning.

As for essential creative and artistic skills, they can be inferred from confessional reflections and conversations with other characters throughout both of the novels. For example, in Erasure true art is characterized by "defying a form ("In my writing my instinct was to defy form, but I very much sought in defying it to affirm it" [12, p.139]), "playing with compositional or even paginal space" $[12$, p. 160] 'depth of artistic expression', 'abundance of irony', 'play with language or ideas'[12, p. 214]. They are the features of Monk's writings, and they are highly 
characteristic of Everett's own writing style, because making art means for him breaking conventions and challenging the reader intellectually.

By contrast, in Erasure Everett provides the features characteristic of craft in literature, although well-made and appreciable: sterile, well-constructed, well-crafted, predictable, commonplace. He attributes these features to popular genre literature produced by the popular authors: "although I did not find any depth of artistic expression or any abundance of irony or play with language or ideas, I found them well enough written, the way a technical manual can be well enough written" [12, c. 215]. "The so-called novel' fathered on Stagg Leigh couldn't be viewed as art because it was not created as a single and inimitable piece of art, it was rather constructed, crafted according to the existing tested models of ghetto novels approved by the editors and the reading audience. The writer followed the instructions for commercial fiction from his agent and it worked out. A 'genuine black piece' utilizes all of the typified categories of African-American literature: the ghetto setting, a 'running' type of narrative, a typical black protagonist - violent, immoral, socially marginalized, a story with a chain of criminal acts and a recognizable language of The Native Son by Richard Wright known as AAVE (African American Vernacular English). Monk, as the writer, didn't use much of his artistic power, but rather a craftsman's skill to put together this object: "It was a parody, certainly, but so easy to construct that I found it difficult to take it seriously even as that" [12, p. 160]. In an attempt to reason for his act of betrayal his art, the Erasure's protagonist observed: "The novel, so called, was more a chair than a painting, my having designed it not as a work of art, but as a functional device, its appearance a thing to be hold, but more a thing to mark, a warning perhaps, a gravestone certainly" [12, p. 208-209]. In other words, the fictional writer proves to be a skillful craftsman to construct a certain type of work which could hardly be judged and appreciated according to artistic criteria, while his own novels possessed lots of graceful features of an artful work, still had been rejected.

Artistic principles of true art in The Water Cure are implied in the following protagonist's remark: "I've been thinking about this mission of art. I don't believe that art is supposed to stand there like an open door or a gate. It is supposed to be a wall, a wall that has to be scaled or a minefield that has to be negotiated" [13, p. 189]. The simile of an open door or gate is applied to craft rather than art in terms of search for meaning, and makes clear, that the reader can easily go through the open door of the meaning in commercial low-brow fiction as there is nothing to challenge the cognitive process. The metaphor of a wall, applied to art, suggests that in the pursuit of meaning the reader is supposed to overcome obstacles shutting the meaning out and literally ascend to the climax of understanding the meaning. Still stronger charged in the context of meaning is the metaphor of the minefield. Being a military term, it suggests a battle, but the question is who battles with whom for the meaning? The reader, the protagonist, the narrator, the author? With whom the meaning has to be negotiated? It is obvious that the military metaphor involves the danger of crossing the minefield of meaning if not properly negotiated. This metaphor also implies the masculine take on the mission of art in this case.

As for the compositional principles of making true art, that is artistic elements used to shape the text, they are not as clearly presented in The Water Cure as in Erasure. They are scattered in confessional fragments where the protagonist regrets not being able to follow the structure of a novel he would love to and explore the subject that bothers him because he can't break away from the generic conventions of the romance novels he produces: "The structure of my romance novels was confining, of course, but what else could I expect, knowing that my business was nor art (that big and nasty word) in any way. But when would my business be art, and when would form and structure not confine me, not constrain me?" [13, p. 62].

If the actual author of the novel The Water Cure Percival Everett were to express his artistic manifesto, he could sound exactly like his character Ishmael Kidder does in the exchange with his agent:

Kidder: "I've been thinking about this mission or art. I don't believe that art is supposed to stand there like an open door or a gate. It is supposed to be a wall, a wall that has to be scaled or a minefield that has to be negotiated"

Agent: "Where is this coming from? What you talking about?"

Kidder: "My art."

Agent: "Are you alright?"

Kidder: "Yes"

Agent: "Fuck art. Who are you kidding? You don't make art. You are going to be rich".

Kidder: "I'd rather be happy."

Agent: "Shut up and settle for rich" [13, p. 189].

In this short exchange the topic of art and craft is taken at its essence, revealing the choice any writer has to make - whether to aim at commercial success and sacrifice their artistic ambitions or follow one's artistic heart and put his commercial success at risk. Ishmael Kidder voted in favour of such a routine 
thing as "bread and butter on the table", having had to sacrifice his artistic ambition and artistic identity. The narrator provides a clearly derived explanation in a passage "on the input of energy" [13, p. 41-42], building his argument on the dependence of every dissymmetric creation of beauty in the natural world on the two extremes of loss of energy and input of energy, and binding his own physical needs to the necessity of it: "It is a dissymmetry in the natural world that creates beauty, the fact a thing cools down, but will never heat up without an input of energy, that a rock will stop rolling, but will not start without an input of energy, that the days lose meaning and will not mean anything new without an input of energy. If I was not paid for my writing, then I would not have food, I would not have energy, I would cool down to ice and cease to move. And the days would mean nothing. That much is clear. Yet sometimes I hate the view so much. It is the dissymmetry of nature that creates beauty the fact that a thing cools down" [13, p 41-42].

The artistic credo pronounced by the writer in The Water Cure contradicts the type of art he produces himself under the name of Estelle Gilliam. Split identity of the writer corrupts him intellectually, as he definitely cannot apply his own vision of "art as a wall or a minefield" to the type of his own art production of "art as an open door". If we listen carefully to the agent's question, "Where is this coming from? What you talking about?" And the writer's answer "My art", we might notice another contradiction: "whose art is he talking about? The only type of art the world knows him by is the type of art he has just recognized as "upsetting, sickening, an insult against literary art". This means there exists some artistic work, unknown yet to the readers and the agent, which will meet the pronounced criteria. The clue to it can be found in the passage about the titles of the novels $[13$, p. 70]. The protagonist mentions the following titles: "The Wind's Kiss, The Kiss of Midnight, Midnight Light, The Light of my Recovery, The Recovery of Passion, Passion's Return to Gentle, The Gentle Storm" [13, p 70] which clearly indicate the type of fiction they belong to - romance novels. Next follows the list of locations where these novels are usually consumed "....a grocery market, airport, train station, drugstore, beauty parlor near you" [13, p. 70]. Those books are real life commercial products, which occupy their place as merchandise in the market relations. When the agent asks the writer about his latest novel The Gentle Storm "What's it about?", he answers "It's about what each and everyone of them is about" [13, p. 67], underscoring formulaic nature and insignificant subject matter of these novels. It's worth paying attention, that Everett uses a kind of word chain game in the given titles - the title of each following novel begins with the last word of the previous one. He does so in order to satirize the existing practice of the junk literature writers to give catchy and appealing titles to the series of novels of a certain genre in order to ensure recognizability and quick sales.

To contrast Estell's authorial identity, a producer of junk literature, the protagonist / writer reveals the titles of the books that inhabit his head, his "least clean room". If Ishmael Kidder dared to speak his own authorial voice, he would title the books as follows: "The Pressure of Observation, Deeper, Analytic of the Sublime, the Fundamental Concepts, The Principia, Other Languages Are All We Have" $[13$, p. 70$]$. The titles clearly reveal Ishmael's true authorial identity's absorption in philosophical speculations and attraction to language and meaning. We may assume that disassembled fragmented passages of The Water Cure are nothing but the draft notes for Ishmael Kidder's unwritten novels, his true Art, sublime Art, the Art he hides from the world in the basement of his mind and insults and tortures it by applying Estelle Gilliam style of writing: "His eyes were like fire, and she felt what little resistance she had left melting like snow on the hood of the minivan after a drive to the soccer field. He pulled her to his iron chest and breathed his delicious breath over her face" [13, p. 90].

The art vs. craft subject matter is specifically emphasized in both novels by the opposite attitudes to it of the writers-protagonists and their literary agents. Agents represent two interdependent institutions: that of the authorship and that of a publish house. The first being aimed at making art, the latter being aimed at making profit. The agents exercise totally professional attitude to fiction evaluating it by the final result: "it will sell" or "it won't sell". The agents are driven by the logic of "sales" and apply the criteria developed by the publish houses to the potential client authors. In both novels, literary agents encourage the writers to let down their artistic principles in favour of mass consumable fiction. Kidder's agent Sally in The Water Cure encourages him to stop being critical about his art and concentrate on making money "If, I've told you once, I've told you a zillion-ca-billion times, don't think about art. Fuck art. Just write" [13, p. 148]. She quite literally urges him into practicing commercial writing by saying: "I do wish you use your powers for good and finish this damn novel" [13, p. 148]. 
Here is a fragment of a conversation between the literary agent and the protagonist, in Erasure:

Monk: “ $<\ldots>$ How do they even know I'm black? Why does it matter?

Agent: "We've been over this before. They know because of the photo on your first book. They know because they've seen you. They know because you are black, for crying out loud."

Monk: "What, do I have to have my characters comb their afros and be called niggers for those people?"

Agent: "It wouldn't hurt" [12, p. 43]

Similar exchange is found in The Water Cure, which most obviously reveals the horizon of the readers' and publish houses' expectations for the authorship and the author's feeling of guilt because of having to compromise his art to craft:

Agent: This is good. It will sell. Tell me this is what you want to write"

Kidder: The title is The Wind's Kiss, "I said. "Of course this isn't what I want to write. I wrote this to make money."

Agent: "And you will. You do this very well."

Kidder: "I know. It upsets me no end. I hate even reading it. I of course can't use my real name"

Agent: "Of course you can't. Or your real face. I've never seen a face so poorly suited for this genre" [13, p. 189]

As it goes from the cited fragments, when art is viewed exclusively from commercial viewpoint, sales criteria are applied not only to the form and content of the novel, but to the identity of the author. By these fragments Everett raises the issue of race in the context of the professional writing activity. Racial identity obviously plays significant role in a consumer society and has to fit a certain expected standard of a certain genre, alongside with catchy titles, specific language, types of characters and twists and turns of the plot. Black writers either have to succumb to the publisher's demands and start reflecting on "black experience" or twist their authorial identity and write race and gender unspecific marketable fiction. Having to do so gave Erasure's protagonist a physical pain: "The pain started in my feet and coursed through my legs, up my spine and into my brain $<$ and I was screaming inside..." [12, p. 61-62].

Black character in The Water Cure has to explain why he had to resort to the pseudonym in order to publish his romance novels: "Initially, I adopted a pseudonymous existence both as a means and as an end. A black man wasn't going to sell many romance novels to school middle-aged perm-headed nail-decaled bus drivers, beauticians and trailer parkers. I also enjoyed my anonymity to some extent. And it served some kind of Zen region of my soul by feeling my lack of ambition or desire for fame and attention, a lack for which I felt great and notably ironic pride" [13, p. 202-203]. Moreover, this passage clearly indicates the target audience for cheap romances. Educated and socially active citizens, capable of intellectual reaction to the questions raised by art are certainly not among the consumers of this type of literature. The narrator's general authorial identity, recognized by him as the author-creator, "the god that I am" [13, p. 147], suffers bitterly at the thought, that by dealing in his romance novels with the subject matter grounded on the level of instincts, passion, emotions, no matter how important they may seem in human life, he distracts his female audience's attention from the really serious questions he could have raised by his art but eventually didn't. As an author he feels ready to bear full responsibility not only for the quality crafting of his fiction, but also for the message he sends to the reader by his art. The subject matter of romance novels simply would not let him "pause in the sky... during some steamy removal of some hat or cape or bra" [13, p. 147] and simply tell his target audience "lost and lonely woman" [13, p. 147] about the greatest concerns of his mind. In Erasure, most ironically, among the audience, giving rapturous critical acclaims to "My Pafology" (renamed as "Fuck') 'piece of shit' novel authored on Stag Leigh were most respected scholars, critics, book club host, and even the fictional writer himself serving as a member of the jury board for the literary award. Thus, Everett satirizes the evil practice of marketing bestsellers in the American culture and makes clear his own despising attitude to it.

In both novels Everett's protagonists take their art seriously. The following exchange between Monk and his dying mother is quite illustrative:

Mother: What have you promised yourself?

Monk: I promised myself once that I would not compromise my art.

Mother: What a fine promise... [12, p. 257].

Monk felt so frustrated by commercial success of "the so called novel" because he failed to keep this promise. "The so called novel" compromised his art, made him deeply ashamed of himself (a self-reflection 'I had a new book out but no one, thank god, knew it was mine' $[12$, p. 255] a warning to the agent "No one is ever going to know that I wrote this piece of shit. Do you understand" [12, p. 255]). The author pictures a deep authorial identity crisis, when his character, being near delirium, first plans his own suicide and then comes to the thought of killing his fake alter ego Stagg, as if he was a real person ("Would I have to kill Stagg to silence him?" [12, p. 248]). 
Similar illustration of Kidder's authorial crisis in the genre of romance is his being on the edge of suicide after reading the abstract of his own romance novel: "A silver bullet (want to be sure it does the job) to my brain is what I consider as I read over this shit. If only I could keep my secret from myself" [13, p. 90]. A silver bullet is exactly the type of weapon, which was believed in earlier times to be able to kill a werewolf, a mysterious creature of dual nature - human, and animal. By mentioning "a silver bullet", Ishmael draws the direct association of himself and a mysterious human with the ability to shapeshift. This unavoidable cliché connection to address the person leading a double life leaves the reader to consider which constituents of the narrator's dual nature are meant: a black man and a white woman writer, which is the most obvious in the given context, or an amiable highly intellectual fiction writer and a monster within him, torturing his victim in the basement of his house. Intellectual pain leading to physical coming from the need to write low rate stories is described in a converted Latin proverb: Cogito, ergo doleo (I think, therefore I suffer) [13, p. 90].

In Erasure's episode of standing naked in front of the bathroom mirror (p. 257-258) Monk is terrified by not seeing the sign of his masculinity. It horrifies the writer to realize that by shifting down to writing junk fiction he had performed, figuratively speaking, "a creative castration" on himself. Physically, he suddenly lost the hallmark of masculinity, and from the creative point of view, he got rid of his aesthetic core, lost a sign of individuality, and now must pay for it, because as a physically disabled man loses the ability to reproduce. Similarly, a creatively "castrated" writer loses the ability to produce a creative art product. Betrayal of his art and the loss of creative core have quickly led to creative impotency, failing when trying to write something really valuable: "I sat up all night for several nights, pretending to look over my notes for a real novel" [12, c. 259]. The motive of justifying oneself in front of one's reflection in the mirror ("I was able to look at my face in the mirror" [12, p. 209]), is realized only after the protagonist had put into words the principle of distinction between art and craft, according to which 'the novel, so called' 'My Pafology' was not a work of art, but a functional device, yet its appearance could be seen as a warning or a gravestone to the author ("my having designed it not as a work of art, but as a functional device, its appearance a thing to behold, but more a thing to mark, a warning perhaps, a gravestone certainly" [12, c. 209]).
In both cases, the fictional authors suffer severe remorse of consciousness for compromising their art and erasing their intellectual authorial identity. The motif of deep despise for commercial fiction perpetrates both novels. It comes as a necessary excuse for the writers to explain their betrayal of the true art. Monk calls his creature "a piece-of-shit novel" and feels as if he let his art down: "I tried to distance myself from the position where the newly sold piece-of-shit novel had placed me vis-a-vis my art" [12, p. 139]. The character ends up in the position of a split personality, one side of which remains committed to the principles of high art, while the other has turned away from it to write low rate commercial fiction on demand and is going to enjoy financial benefits from it "I was not, apparently, going to turn away the check" [12, p. 139]. Ishmael Kidder could take credit for his novels, signed by pseudonym, no matter how artistically dissatisfying they were to him as a man-writer and how bitterly they hurt his authorial dignity, because they were still "well-written" by his own assessment although formulaic and predictable [13, p. 147]. He admitted that romance novels had no great artistic value, "they were what they were" [13, p. 147] that means he used his writer's craft to advantage to produce a commercial piece as a qualified professional. However, he also regrets being confined to one genre "What if I, my character, am a man infected, soaked with the disease of the genre" [13, p. 148]. His real authorial identity of an intellectual writer is trapped in a vicious circle of genre confinement.

In conclusion, Percival Everett continues the discussion on art, craft and authorial identity, expressing his severe criticism of the contemporary publishing world. $\mathrm{He}$ is sure, that in post-modernist times of commercialization of not only art but of criticism itself "art (and criticism of it) is measured not by artistic standards, but by how well the commodifying culture exploits it and is exploited by it" [14, p. 18]. The research shows that concept of art of writing is given in the novels Erasure and The Water Cure as a threefold set of skills: cognitive, creative and artistic, as opposite to the concept of craft as a skillful reproduction of the existing pattern. The subject matter of art vs craft is revealed through the subject matter of a black writer's authorial identity. Everett urges the critics and the publishers to rethink what African American actually means and change the criteria for works to be considered as artful representation of the author's worldview.

There are quite a few problems in Everett's works that can arouse scholarly interest. Some of them are intertextual links with the works of his literary prede- 
cessors, postmodernist features of his writing, such as the multilayer structure of his fiction, oriented on multiple interpretation, narrative strategies and multiple points of view, pluralism of language and cultural contexts, use of double coding technique, play with citations, allusions and cultural and linguistic codes etc.

\section{References:}

1. Sally J. Markowitz. The distinction between Art and craft. URL: https://www.jstor.org/stable/3333159.

2. Perspectives on Percival Everett/ed. Keith B. Mitchell and Robin G. Vander. University Press of Mississippi, 2013. $167 \mathrm{p}$.

3. Bauer Sylvie. «Nouns, Names, Verbs» in The Water Cure by Percival Everett, or "Can a Scream be Articulate». Revue francaise d'etudes americaines. 2011/2. N. 128. P. 99-108.

4. Feith Michel. The Art of Torture in The Water Cure by Percival Everett. Revue francaise d'etudes americaines. 2012/2. N. 132. P. 90-104.

5. Tissut A. L.Percival Everett's The Water Cure : A Blind Read. Sillages critiques. Iss. 17, 2014. P. 1-10. URL: https://journals.openedition.org/sillagescritiques/3496.

6. Cannon Uzzie Teresa. Against the Grain: Black Masculine Narrative Insurgency in Contemporary Fiction. Greensboro USA today. 2004. 178 p.

7. Roof Judith. Everett's Hypernarrator. Canadian Review of American Studies, Vol. 43, November 2, Summer 2013. P. 202-215.

8. Russett Margaret. Race under Erasure. Callaloo. Vol. 28, November 2, Spring, 2005. P. 358-368.

9. Morton Seth. Locating the Experimental Novel in Erasure and The Water Cure. Canadian Review of American Studies. Vol. 37. November 3, 2007. P. 189-201.

10. Stewart Anthony. Uncategorizable Is Still a Category: An Interview with Percival Everett. Canadian Review of American Studies. Vol. 37. November 3, 2007. P. 216-224.

11. Shkuropat M. "Am I a Rougue Palmerin or Lancelot?": Authorial Identity in the Novels Erasure and The Water Cure By Percival Everett. Науковий Вісник Міжнародного Гуманітарного Університету. Серія «Філологія» № 50. 2021.

12. Everett Percival. Erasure. Minneapolis: Graywolf Press, 2001. 265 p.

13. Everett Percival. The Water Cure . Saint Paul, Min.: Graywolf Press, 2007. 216 p.

14. Everett Percival. F/V: Placing the experimental novel. Callaloo. Vol. 22, November 1, Winter, 1999. P. 18-23.

\section{ШкУропаТ М. Ю. «ЦЕ ЛАЙНО, АЛЕ ВОНО ПРОДАЕТЬСЯ»: МИСТЕЦТВО ТА РЕМЕСЛО В POMAHAX «ERASURE» TA «THE WATER CURE » ПЕРСІВАЛЯ ЕВЕРЕTTA}

Стаття розглядає тему мистецтва та ремесла, як вони розкриваються у романах сучасного американського письменника Персіваля Еверетта Erasure (Стирання) та The Water Cure (Лікування водою). Романи Еверета свідчать про те, щьо автор настільки серйозно ставиться до теми мистецтва, що знову повертається до неї на пізніших етапах своєї письменницької кар'єри, не змінюючи точки зору, а посилюючи ії, забезпечуючи таким чином грунт для контрастно-порівняльного аналізу. Дослідження робить спробу простежити розгортання концепції письменницького мистецтвва як потрійного набору навичок: пізнавальних, творчих та художніх, на відміну від концепчії ремесла як вмілого відтворення існуючого зразка. Аналіз репрезентації теми в обох романах проводиться у порівняльному режимі та виявляє ї̈ зв'язок із темою авторської ідентичності чорношкірого автора в американській культурі. Коли мистеитво розглядається виключно з комериійної точки зору, критерії продажу застосовуються не тільки до форми та змісту, а й до авторської ідентичності. Еверетт порушує проблему раси в контексті професійної письменницької діяльності. Расова ідентичність, очевидно, відіграє значну роль у суспільстві споживання і має відповідати певним очікуваним стандартам певного жанру, поряд із помітними назвами, специифічною мовою, типами персонажів та поворотами сюжету. Чорношкірим письменникам доводиться або піддаватися на вимоги видавиів і починати відтворювати «чорний досвід» в творах, або змінювати свою авторську ідентичність $і$ писати комериійну расово та гендерно неспецифічну літературу. Стверджується, ще розуміння героями мистеитва та ремесла має міџний зв'язок із поглядами автора. Еверетт не перестає висловлювати протест проти класифікації літератури за кольором шкіри ї̈ автора.

Ключові слова: мистецтво, ремесло, авторська ідентичність, Персіваль Еверетт, Erasure, The Water Cure. 